\title{
Early verb development in one Austrian child ${ }^{\prime}$
}

\author{
Sabine Klampfer \\ Wien \\ sabine.klampfer@univie.ac.at
}

\section{Introduction}

The purpose of this paper is to trace the early development of verbs (first 50 verb lemmas) in one Austrian child. The paper focusses on verb morphology, and especially on the emergence of first verb paradigms.

\section{1. (Austrian) German verbal system}

German is a 'weakly inflecting' language (cf. Dressler 1997a) with moderately rich verb morphology. Austrian German is even weaker inflecting than Standard High German.

\subsection{Grammatical categories}

German verbs encode the grammatical categories of person, number, tense, mood and voice. There exists no grammatical verbal category of aspect in German.

Person $\left(1^{\text {st }}, 2^{\text {nd }}, 3^{\text {rd }}\right)$ and number $(\mathrm{sg}, \mathrm{pl}$ ) are expressed fusionally by verbal suffixes (and by subject pronouns which are obligatory unless there is ellipsis, or if the noun renders a $3^{\text {rd }}$ person pronoun superfluous). The following table (tab. 1) gives an overview of the suffixes used in the present indicative and in the imperative. Parentheses and slashes indicate possible alternations in colloquial Austrian German.

\begin{tabular}{|c|c|c|c|c|}
\hline & \multicolumn{2}{|c|}{ PRES. INDICATIVE } & \multicolumn{2}{c|}{ IMPERATIVE } \\
\cline { 2 - 5 } & Sg. & Pl. & Sg. & Pl. \\
\hline $\mathbf{1}^{\text {st }}$ Pers. & spiel-(e) & spiel-(e)n ${ }^{2}$ & & spiel-(e)n wir!/ \\
& & & & -ma! \\
\hline $\mathbf{2}^{\text {nd }}$ Pers. & spiel-st & spiel-t/-ts & spiel- $\varnothing !$ & spiel-t!/-ts! \\
\hline $\mathbf{3}^{\text {rd }}$ Pers. & spiel-t & spiel-(e)n & & \\
\hline
\end{tabular}

Table 1: Person and number marking in the present indicative and imperative: the weak German verb spielen 'to play'

Within the category tense, spoken Austrian German distinguishes between present, future, perfect, and pluperfect. In contrast to Northern German varieties, the synthetic preterite is unproductive in spoken Austrian German (except for the verb sein 'to be'). The present is formed synthetically. Perfect, pluperfect and future tense are expressed by periphrastic constructions, i.e. by combination of Aux (haben 'to have', sein 'to be') + PP (e.g. er hat gespielt 'he played / has played') and Aux (werden 'to become') + INF (e.g. er wird spielen 'he

1 Written by Sabine Klampfer after discussion with Wolfgang U. Dressler. We would like to thank Dagmar Bittner and Marianne Kilani-Schoch for their comments on an earlier version of this paper. The present study is supported by the "Fonds zur Förderung der wissenschaftlichen Forschung" (Project number P13681-SPR).

2 In cases in which verb forms of the 1. Pl. are directly followed by the colloquial subject pronoun ma, the alternations observed in the imperative hold also for the indicative. 
will play') respectively. Within the category mood, spoken Austrian German distinguishes between indicative, imperative and conditional ( = conjunctive II), the last one being formed analytically in Standard Austrian German (e.g. ich würde spielen 'I would play'), and synthetically in some Austrian dialects (e.g. [i fpy:lat]). Passive voice is expressed by the construction Aux (werden 'to become' for the event and sein 'to be' for the stative passive) + PP (e.g. es wird gespielt' it is played').

\subsection{Inflectional classes and productivity}

Following Bittner (1996: 83-109), Dressler (in prep.) proposes a subdivision of the German verb - according to different patterns of stem vowel change (Umlaut (U), Ablaut (A)) and weak vs. strong inflectional properties of category symbolization - into (at least) 15 different inflectional microclasses. This classification established for the adult language appears however to be too detailed for the study of child language. For example, in spoken Austrian German, children are hardly ever exposed to preterite forms (except for the verb sein 'to be' and for fairytales) and therefore children before the age of 3;0 are rather unlikely to make distinctions between microclasses which differ by the use of Ablaut in the preterite. Collapsing microclass distinctions which are of little relevance for small Austrian children, German verbs may thus be grouped into the following classes (cf. Klampfer, Maillochon, Bassano \& Dressler 1999, Dressler \& Klampfer 2000); the forms given are Inf., 3. Sg. Pres.Ind., 1.Pl. Pres.Ind., 2.Sg. Imp., PP:

Class 1: weak verbs e.g. spielen, schauen spielen 'to play': er spielt, wir spielen, spiel!, gespielt

Class 1': weak verbs (+A) e.g. brennen, senden brennen 'to burn': es brennt, wir brennen, brenn!, gebrannt

Class 2: strong verbs (+A) e.g. greifen, bleiben, fließen, biegen, rinnen, singen bleiben 'to stay': er bleibt, wir bleiben, bleib!, geblieben

Class 3: strong verbs $(+1 \mathrm{U})$ e.g. schlafen, fahren schlafen 'to sleep': er schläft, wir schlafen, schlaf!, geschlafen

Class 3': strong verbs (-U) e.g. kommen, rufen kommen 'to come': er kommt, wir kommen, komm!, gekommen

Class 4: strong verbs $(+2 \mathrm{U})$ e.g. lesen, geben lesen 'to read': er liest, wir lesen, lies!, gelesen

Class 5: strong verbs $(+2 \mathrm{U},+\mathrm{A})$ e.g. quellen, brechen, stehlen, sterben brechen 'to break': er bricht, wir brechen, brich!, gebrochen

Modals: können, müssen, wollen, mögen, sollen, dürfen; wissen können 'can': 1.Sg.Pres.Ind. ich kann, er kann, wir können, gekonnt

Auxiliaries / suppletive auxiliaries as main verbs: sein, haben, werden; tun sein 'to be': 1.Sg.Pres.Ind. ich bin, er ist, wir sind, gewesen

Suppletives e.g. gehen, bringen gehen 'to go': er geht, wir gehen, geh!, gegangen 
Class 1 consists of German weak verbs. Class 1 (e.g. spielen) is the only productive verb class $^{3}$ (cf. Dressler 1997b). Subclass 1' (e.g. brennen) is formed by unproductive weak verbs taking Ablaut in the PP. Classes 2-5 consist of German strong verbs. ${ }^{4}$ Verbs of class 2 (e.g. bleiben) take Ablaut in the PP. Class 3 (e.g. schlafen) is represented by verbs displaying a stem vowel change in the 2 . and 3 . Sg. Pres.Ind. In colloquial speech this Umlaut may be levelled. Verbs of subclass $3^{\prime}$ (e.g. kommen) never take Umlaut. In class 4 (e.g. lesen), Umlaut is used in the $2 . \mathrm{Sg}$. Imp. as well. Class 5 verbs (e.g. brechen) take both Umlaut and Ablaut.

Despite different details in their paradigms, modal verbs (e.g. können) share several morphosyntactic and semantic properties and thus are grouped together for the purpose of this paper. Auxiliaries and suppletive auxiliaries as main verbs are put together for the same reason. Suppletive main verbs (e.g. gehen) will be analyzed separately.

\subsection{Other important characteristics}

Another important characteristic of German verbs are separable stressed prefixes such as weg 'away' in the verb weggehen 'to go away'. In matrix clauses of the present indicative and in the imperative, they get separated from the base (e.g. er geht weg 'he goes away', geh weg! 'go away!'). Although German verb prefixes may be used to distinguish between „Aktionsarten“ (e.g. durative essen 'to eat' vs. non-durative aufessen 'to eat up'), prefixed verb forms often bear different lexical meanings and thus will be treated as different verb lemmas.

\section{The database}

\subsection{General data description}

The present study is based on longitudinal spontaneous speech data of the Austrian girl Katharina. Katharina is the second of three children of an Austrian couple living in Vienna. She was audiorecorded in free play situations (mostly in interaction with the mother) from the age of $1 ; 6$ to $3 ; 0$, yielding 34 spontaneous speech sessions of about 30 minutes each. The data were transcribed and morphologically coded according to the norms of the international child

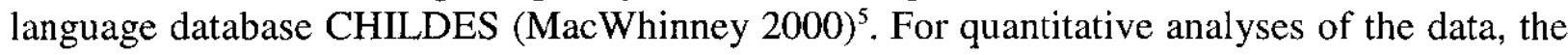
CLAN programs of CHILDES were used.

\subsection{Data analyzed for this contribution}

This study focusses on the period of Katharina's first 50 verb lemmas, thus covering the period from age $2 ; 0.18$ to $2 ; 4.22$ (cf. tab. 2). For the following analyses, recording sessions within one month of age have been grouped together.

3ote that for German verbs, the factor 'productivity' cannot be separated from 'lemma frequency' and 'default', since the only productive verb class 1 has the highest lemma frequency and functions also as default class.

4 In contrast to weak verbs, German strong verbs take the suffix -en in the PP (e.g. class 1 ge-spiel-t 'played' vs. class 3 ge-schlaf-en 'slept').

5 Data collection and transcription was made by Brigitta Müller (and Maria Sedlak). Sabine Klampfer was responsible for the automatic morphological coding of the data (using CLAN's MOR utility) and for the creation of the full-form lexicon GER.LEX. which was used for this purpose. Thanks are due to Steven Gillis for introduction to MOR-coding. 


\begin{tabular}{|c|c|c|c|c|}
\hline Session & Age & Duration & Productions & $\begin{array}{c}\text { Analyzed } \\
\text { utterances }^{6}\end{array}$ \\
\hline ka109 & $2 ; 00.18$ & $17 \mathrm{~min}$. & 135 & 102 \\
\hline kat10 & $2 ; 00.21$ & $10 \mathrm{~min}$. & 29 & 27 \\
\hline kat11 & $2 ; 00.24$ & $10 \mathrm{~min}$. & 46 & 39 \\
\hline kat12 & $2 ; 00.29$ & $40 \mathrm{~min}$. & 215 & 192 \\
\hline kat13 & $2 ; 01.04$ & $10 \mathrm{~min}$. & 98 & 79 \\
\hline kat14 & $2 ; 01.18$ & $6 \mathrm{~min}$. & 78 & 63 \\
\hline kat15 & $2 ; 01.28$ & $17 \mathrm{~min}$. & 78 & 65 \\
\hline kat16 & $2 ; 02.05$ & $25 \mathrm{~min}$. & 96 & 80 \\
\hline kat17 & $2 ; 02.11$ & $7 \mathrm{~min}$. & 58 & 46 \\
\hline kat18 & $2 ; 03.07$ & $32 \mathrm{~min}$. & 176 & 147 \\
\hline kat19 & $2 ; 03.12$ & $30 \mathrm{~min}$. & 206 & 157 \\
\hline kat20 & $2 ; 03.21$ & $30 \mathrm{~min}$. & 174 & 157 \\
\hline kat21 & $2 ; 04.10$ & $30 \mathrm{~min}$. & 203 & 171 \\
\hline kat22 & $2 ; 04.22$ & $30 \mathrm{~min}$. & 186 & 164 \\
\hline
\end{tabular}

Table 2: Katharina's longitudinal corpus: characteristics of analyzed sessions from $2 ; 0$ to $2 ; 4$

\subsection{Learning strategy and demarcation of phases}

In comparison with other German speaking children, Katharina's onset of speech is rather late, namely at around 1;8 - but she advances rapidly later on. In terms of Peters and Menn (1993: 745), her approach to language can be characterized as 'formulaic': i.e. she initially focusses on multisyllabic chunks of speech rather than on single words. Nursery rhymes and songs play an important role in Katharina's early acquisition phase (Müller 1997: 61ff.).

Katharina enters the protomorphological phase at about 2;3, the onset of modularized morphology can be dated around 2;9 (cf. Müller 1997: 67; Vollmann, Sedlak, Müller \& Vassilakou 1997; Anđel, Klampfer, Kilani-Schoch, Dressler \& Kovačević in press). ${ }^{7}$

In Katharina's data, the onset of protomorphology $(2 ; 3)$ can be said to coincide with a clear increase of verb production ("verb spurt", see also section 4.1., fig. 2). At the same time the first two-member mini-paradigms and the first overgeneralization error ${ }^{8}$ are observed (see sections 5.2., 6.2.). ${ }^{9}$ One month later, i.e. at $2 ; 4$, first periphrastic verb constructions appear (e.g. Mod+Inf kann nicht a(n)zieh(e)n 'can't put on', Perfect is( $t)$ umgefallen 'has fallen over'). As to nouns, the beginning of protomorphology is characterized by an increase of plural forms. One month later, the first overgeneralization error is observed ( $2 ; 4$ Handschuhn <-- Handschuhe 'gloves', cf. Sedlak, Klampfer, Müller \& Dressler 1998). Furthermore, the onset of protomorphology goes together with a remarkable increase of the overall lexical

6 To qualify as an utterance, a production had to include at least one mcaningful unit resembling a German word in form and meaning. Babbling, vocalizations and completely incomprehensible strings were not considered uttcrances. Citations (e.g. nursery rhymes and songs) and direct imitations were excluded from the analysis.

7 Note that Vollmann et al. (1997:65) have defined 2;3 as transition phase from pre-to protomorphology. For the purpose of this paper, this short transition phase has been included into protomorphology. As has been shown by Allen (1996), creative errors such as overgeneralizations provide the strongest evidence for the beginning morphological productivity of a child, since morphological productivity is the only adequate explanation for these types of errors.

9 For similiar findings with a German child revealing a correlation between verb spurt and first overgencralizations see Elsen 1998 (140-143). 
diversity in the child's language (measure $\mathrm{D}^{10}$, cf. Richards \& Malvern 1999). As can be seen in figure 1, both the weak measure (i.e. all word classes), and the strict measure (paralexicals such as fillers, onomatopoetics, interjections, communicators excluded, cf. Bassano, Maillochon \& Eme 1998: 502f.) of lexical diversity show a considerable increase from age $2 ; 3$ onwards. This observation further corroborates the hypothesis that there exists a close relationship between lexical and morphological development ("critical mass hypothesis", cf. Marchman \& Bates 1994; Bates, Dale \& Thal 1995: 120). ${ }^{11}$

Figure 1

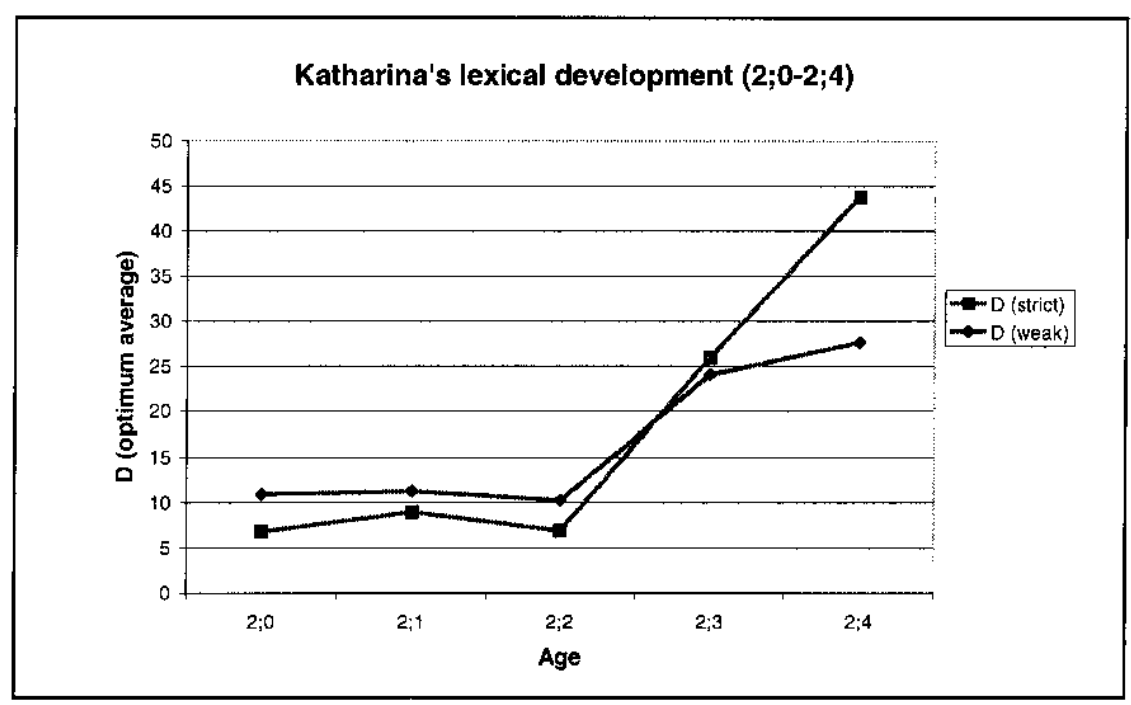

Although a beginning increase of syntactic complexity is attested at the onset of protomorphology (e.g. first occurrences of Mod+Inf - constructions and periphrastic past, first advance of article and subject pronoun use), no clear syntactic spurt can be observed in this period. At 2;3 Katharina's MLU (words) is at 1,4 [SD 0,7], and will excede the level of 2 only three months later, i.e. at 2;6: MLU (words) 2,5 [SD 1,7]. ${ }^{12}$

\section{Predecessors of verbs}

Before or simultaneously with the emergence of first verbs (i.e. before and at age 2;0) Katharina uses separable verb prefixes in predicative function, e.g.:

(1) $1 ; 8$ ? we(g) 'away' for taking away a toy donkey

$1 ; 11$ weg 'away' for 'daddy is gone'

2;0 da her 'hither' for taking a toy car out of a box

$2 ; 0 j u(=z u)^{\prime}$ 'closed' for 'the door is closed'

${ }^{10} \mathrm{D}$ is a new measure of lexical diversity developed by Brian Richards and David Malvern and recently also available within the CLAN-package (VOCD, cf. MacWhinney 2000). D is comparable to Type-Token Ratio (TTR), but is independent of sample size; it is calculated by fitting empirical data to the theoretical curve of TTR plotted against Token size. Note that the value D obtained in figure 1 corresponds to a TTR in which types equal lemmas.

11 For the relevance of a critical mass of lexical items as possible prerequisite for the acquisition of verb semantics see Behrens 1999 (36-38).

12 For MLU, repetitions and retracings have been excluded. 
Examples of isolated use of verb prefixes can still be found at the end of the time period analyzed for this study, e.g.: ${ }^{13}$

(2) 2;4 ich kanns auf Mama! ( = ich kann es aufmachen Mama) 'I can open it mum'

Other possible predecessors of verbs observed in the Katharina data are onomatopoetics (cf. also Müller 1997: 65). But all examples before age 2;0 might equally be interpreted as nominal uses. Only at 2;0 first clear examples of onomatopoetics in predicative function appear:

(3) $1 ; 6 \mathrm{brm}$ for the noise made by toy cars (or nominal for car)

$1 ; 9 \mathrm{kra}$ for crowing (or nominal for birds)

$1 ; 10$ wawa for barking (or nominal for dog)

$1 ; 11 \mathrm{i} a$ for neighing (or nominal for horse)

2;0 Kuh muh (= die Kuh macht muh) 'the cow is lowing'

\section{Emergence of verb forms}

\subsection{Verb production}

As can be seen in figure 2, verbs start to emerge with Katharina at the age of $2 ; 0$. From $2 ; 3$ (i.e. from the beginning of protomorphology) onwards a clear increase of verb production ("verb spurt") is observed. ${ }^{14}$ In this figure, we have distinguished a) verb lemmas (i.e. verbs as lexical entries), b) verb types (i.e. different verb forms per lemma), and c) verb tokens (i.e. occurrences for each specific verb form). Percentages have been calculated with respect to the total number of analyzed child utterances per month, and thus show the steady increase of verbs.

Figure 2

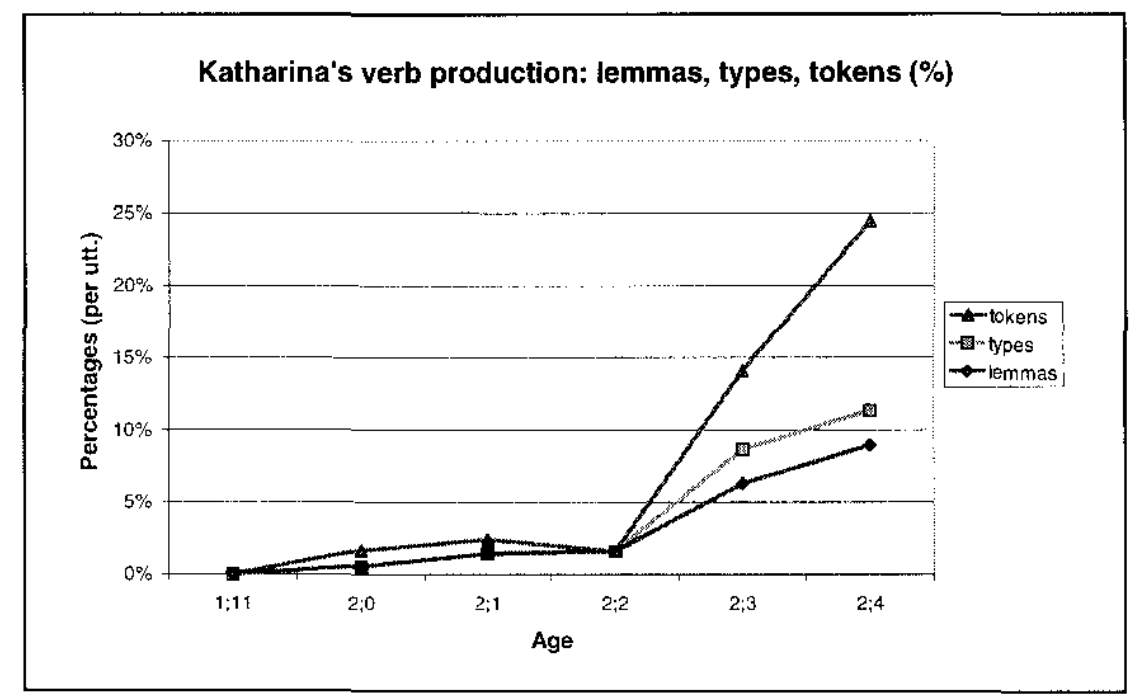

13 Note that isolated use of separable verb prefixes such as in (1) also oecurs in adult language. Examples 2 and 4 of (1) presuppose the elision of the copula sein 'to be', and examples 1 and 3 of (1) as well as the example in (2) the elision of a lexical verb.

14 A tiner subdivision of data into different recording sessions per month shows a first remarkable verb spurt in the first recording session of $2 ; 3$, i.e. at $2 ; 3.7$. 
The respective absolute numbers are given in tables $3 \mathrm{a}$ and $3 \mathrm{~b}$. Table $3 \mathrm{~b}$ also shows the amount of erroneous types and tokens (for error analysis see section 6 ). ${ }^{15}$

\begin{tabular}{|c|c|c|c|}
\hline age & $\begin{array}{c}\text { utterances with } \\
\text { verbs }\end{array}$ & $\begin{array}{c}\text { analyzed } \\
\text { utterances }\end{array}$ & $\begin{array}{c}\text { utt. with verbs } \text { ' } \\
\text { analyzed utt. }\end{array}$ \\
\hline $2 ; 0$ & 6 & 360 & $1,7 \%$ \\
\hline $2 ; 1$ & 5 & 207 & $2,4 \%$ \\
\hline $2 ; 2$ & 2 & 126 & $1,6 \%$ \\
\hline $2 ; 3$ & 63 & 461 & $13,7 \%$ \\
\hline $2 ; 4$ & 80 & 335 & $23,9 \%$ \\
\hline Total & $\mathbf{1 5 6}$ & $\mathbf{1 4 8 9}$ & $\mathbf{1 0 , 5 \%}$ \\
\hline
\end{tabular}

Table 3a: number of utterances with verbs with respect to the number of analyzed utterances

\begin{tabular}{|c|c|c|c|c|c|c|}
\hline age & lemmas & types & tokens & lemmas \% & types \% & tokens \% \\
\hline $2 ; 0$ & 2 & $2\left(I^{*}\right)$ & $6\left(I^{*}\right)$ & $0,6 \%$ & $0,6 \%$ & $1,7 \%$ \\
\hline $2 ; 1$ & 3 & $3\left(I^{*}\right)$ & $5\left(I^{*}\right)$ & $1,4 \%$ & $1,4 \%$ & $2,4 \%$ \\
\hline $2 ; 2$ & 2 & $2\left(I^{*}\right)$ & $2\left(I^{*}\right)$ & $1,6 \%$ & $1,6 \%$ & $1,6 \%$ \\
\hline $2 ; 3$ & 29 & $40\left(I^{*}\right)$ & $65\left(17^{*}\right)$ & $6,3 \%$ & $8,7 \%$ & $14,1 \%$ \\
\hline $2 ; 4$ & 30 & $38\left(7^{*}\right)$ & $82\left(14^{*}\right)$ & $9,0 \%$ & $11,3 \%$ & $24,5 \%$ \\
\hline Total & $\mathbf{5 0}$ & $\mathbf{7 1}$ & $\mathbf{1 6 0}$ & $\mathbf{3 , 4 \%}$ & $\mathbf{4 , 8 \%}$ & $\mathbf{1 0 , 7 \%}$ \\
\hline
\end{tabular}

Table $3 \mathrm{~b}$ : number of verb lemmas, types (incorrect types) and tokens (incorrect tokens), percentages with respect to the number of analyzed utterances

\subsection{Verb categories before protomorphology}

Katharina's verb production before protomorphology (i.e. 2;0-2;2) is limited to very few instances of verb forms in the $1^{\text {st }}$ and $3^{\text {rd }}$ person present indicative (e.g. b(r)auchich 'I need', dais 'there is') and $2^{\text {nd }}$ person imperative (schau Mama! 'look mum!'). As can be seen in table 4a, all forms - except for one single occurrence of 3.Sg. at 2;2 (d(r)eht ( = dreht sich) 'is turning') can be characterized as frozen (cf. section 4.4.).

\begin{tabular}{|c|c|c|c|c|}
\hline Age & $\begin{array}{r}\operatorname{Pr} \\
1 . \mathrm{Sg} .\end{array}$ & $\begin{array}{l}\text { 1d. } \\
\text { 3.Sg. }\end{array}$ & Imp. 2.Sg. & Total \\
\hline $2 ; 0$ & $\begin{array}{c}1 / 5 \\
(1 / 5)\end{array}$ & & & $1 / 5$ \\
\hline $2 ; 1$ & & $\begin{array}{c}1 / 1 \\
(1 / 1)\end{array}$ & $\begin{array}{c}1 / 3 \\
(I / 3)\end{array}$ & $2 / 4$ \\
\hline $2 ; 2$ & & $1 / 1$ & & $1 / 1$ \\
\hline Total & $1 / 5$ & $2 / 2$ & $1 / 3$ & $4 / 10$ \\
\hline
\end{tabular}

Table 4a: Katharina's verb categories before protomorphology (types/tokens). Frozen forms are indicated by parentheses. Incorrect forms are listed separately (cf. table $4 b$ )

Table $4 \mathrm{~b}$ shows the distribution of incorrect verb forms with regard to verb categories (best guess analysis). As one can see, all erroneous forms have been attributed the target category 3.Sg. Pres.Ind. (see also section 6).

15 table $3 \mathrm{~b}$ the term 'incorrect' refers to form errors (cf. section 6.1.) and class shifts (cf. 6.2.). Agreement errors (cf. 6.3.) have not been listed separately. The same holds for tables $4 \mathrm{~b}$ and $5 \mathrm{~b}$. 


\begin{tabular}{|c|c|c|}
\hline Age & $\begin{array}{c}\text { Pres. Ind. } \\
\text { 1.Sg. 2.Sg. 3.Sg. }\end{array}$ & Total \\
\hline $2 ; 0$ & $1 / 1$ & $1 / 1$ \\
\hline $2 ; 1$ & $1 / 1$ & $1 / 1$ \\
\hline $2 ; 2$ & $\begin{array}{c}1 / 1 \\
(1 / 1)\end{array}$ & $1 / 1$ \\
\hline Total & $3 / 3$ & $3 / 3$ \\
\hline
\end{tabular}

Table 4b: Distribution of incorrect verb types and tokens with regard to verb categories.

Frozen forms are indicated by parentheses

\subsection{Verb categories in protomorphology}

At the onset of protomorphology (at $2 ; 3$, see table 5a), Katharina starts to use $1^{\text {st }}$ singular forms more frequently (e.g. hol ich 'I go for', ich sitze 'I sit', ich halt'I hold'). The use of 3.Sg. Pres.Ind. is still very restricted. ${ }^{16}$ At 2;3 also the first infinitives (e.g. schlafen 'to sleep') and past participles (e.g. umged(r)eht 'turned around') appear. From 2;4 on, she uses 3.Sg. Pres.Ind. more often (e.g. (sch)meckt 'tastes good', (s)pielt 'plays', kommt 'comes'), and the first example of 2.Sg. Pres.Ind. (has $(t) d u$ 'do you have') is observed. At the same age, Katharina starts to use compound past ( $i s(t)$ umgefallen 'has fallen over').

\begin{tabular}{|c|c|c|c|c|c|c|c|c|}
\hline Age & 1.Sg. & $\begin{array}{l}\mathrm{es} . \mathbf{I} \mathbf{I} \\
\mathrm{C} \mathbf{S g}\end{array}$ & 3.Sg. & $\begin{array}{l}\text { Imp. } \\
\text { 2.Sg. }\end{array}$ & Inf. & $\mathbf{P P}$ & $\begin{array}{c}\text { Comp. } \\
\text { Past } \\
\end{array}$ & Total \\
\hline $2 ; 3$ & $\begin{array}{l}6 / 10 \\
(2 / 4) \\
\end{array}$ & & $\begin{array}{c}3 / 5 \\
(2 / 4) \\
\end{array}$ & $\begin{array}{c}2 / 4 \\
(1 / 1) \\
\end{array}$ & $11 / 14$ & $2 / 2$ & & $24 / 35$ \\
\hline $2 ; 4$ & $\begin{array}{c}9 / 25 \\
(2 / 10) \\
\end{array}$ & $1 / 2$ & $\begin{array}{l}8 / 19 \\
(2 / 2) \\
\end{array}$ & $1 / 1$ & $6 / 13$ & $1 / 1$ & $1 / 1+1 / 1$ & $28 / 63$ \\
\hline Total & $13 / 35$ & $1 / 2$ & $9 / 24$ & $3 / 5$ & $15 / 27$ & $2 / 3$ & $1 / 1+1 / 1$ & $45 / 98$ \\
\hline
\end{tabular}

Table 5a: Katharina's verb categories in protomorphology (types/tokens). Frozen forms are indicated by parentheses. Incorrect and ambiguous forms are listed separately (cf. table 5b)

\begin{tabular}{|c|c|c|c|c|c|c|}
\hline Age & $\begin{array}{l}\text { Pres. Ind. } \\
\text { 1.Sg. 2.Sg. 3.Sg. }\end{array}$ & 3.PI. & Inf. & $\mathbf{P P}$ & $\begin{array}{c}\text { Comp. } \\
\text { Past }\end{array}$ & Total \\
\hline $\begin{array}{l}2 ; 3 \\
\text { incorrect } \\
\text { ambiguous }\end{array}$ & $3 / 5$ & & $\begin{array}{c}6 / 7 \\
4 / 13 \\
\end{array}$ & $3 / 3$ & $1 / 1+1 / 1$ & $\begin{array}{c}14 / 17 \\
4 / 13\end{array}$ \\
\hline $\begin{array}{l}2 ; 4 \\
\text { incorrect } \\
\text { ambiguous }\end{array}$ & $\begin{array}{l}3 / 9 \\
1 / 1\end{array}$ & $2 / 2$ & $3 / 4$ & $2 / 3$ & & $\begin{array}{c}7 / 14 \\
4 / 5\end{array}$ \\
\hline Total & $7 / 15$ & $2 / 2$ & $12 / 24$ & $5 / 6$ & $1 / 1+1 / 1$ & $28 / 49$ \\
\hline
\end{tabular}

Table 5b: Distribution of incorrect and ambiguous verb types and tokens with regard to verb categories

The distribution of incorrect and ambiguous verb forms with regard to verb categories (best guess analysis) is given in table 5b. Incorrect forms fall into the target categories $3 . \mathrm{Sg}$. Pres. Ind., 3.Pl. Pres.Ind. Inf., PP and compound past. Most ambiguous forms are observed in the category of infinitives - this is due to the homophony of Inf. with 1. and 3.P1. Pres.Ind. (for a more detailed error analysis see section 6).

16. Similarly, 1.Sg. Pres.Ind. emerges earlier in mini-paradigms than 3.Sg. Pres.Ind. (see section 5.2.). 


\subsection{Frozen forms}

Following the definition of frozen forms given in the Introduction to this volume, frozen forms (indicated by parentheses in tab. 4 and 5) have been further divided into (i) amalgams: in the observed period, Katharina uses amalgams of the 1. and 3. Sg. Pres.Ind., but $1^{\text {st }}$ person amalgams emerge earlier and are more frequent (e.g. brauchich 'I need', weissinet 'don't know', habschon 'already have') (cf. Klampfer, Vollmann \& Dressler 1999); (ii) regulative or phatic forms (e.g. na geh! 'it's too bad', schau! 'look', macht nix 'no problem'). Imitations of verb forms are rare in the Katharina corpus and have been excluded from analysis (cf. footnote 6).

\subsection{Inflectional classes}

The next table (tab. 6), gives an overview of the distribution of Katharina's verbs (lemmas, types, tokens) with regard to inflectional classes (cf. section 1.2.). As one can see, in the observed period, verbs of class 1 are most frequent (not only in lemma, but also in type and token frequency). For classes 1-5 the following order of emergence can be observed: class 1 (e.g. brauchen 'need') > class 2 (e.g. rinnen 'to run/flow') > class 3 (e.g. schlafen 'to sleep'), class 3 ' (e.g. kommen 'to come'), class 4 (e.g. reingeben 'to put into') > class 5 (e.g. wegnehmen 'to take away'). Suppletives and suppletive auxiliaries as main verbs emerge early and are relatively frequent. Modals are attested from 2;3 onwards, first auxiliaries are observed at $2 ; 4$.

\begin{tabular}{|l|c|c|c|c|c|c|c|c|c|c|c|}
\hline Age & Class1 & Class2 & Class3 & Class3 & Class4 & Class5 & Suppl & Suppl:aux & aux & mod & Total \\
\hline $2 ; 00$ & $1 / 1 / 5$ & & & & & & $1 / 1 / 1$ & & & & $\mathbf{2 / 2 / 6}$ \\
\hline $2 ; 01$ & $1 / 1 / 3$ & $1 / 1 / 1$ & & & & & & $1 / 1 / 1$ & & & $\mathbf{3 / 3 / 5}$ \\
\hline $2 ; 02$ & $1 / 1 / 1$ & & & & & & & $1 / 1 / 1$ & & & $\mathbf{2 / 2 / 2}$ \\
\hline $2 ; 03$ & $11 / 14 / 22$ & $2 / 2 / 2$ & $5 / 7 / 10$ & $2 / 2 / 2$ & $3 / 3 / 3$ & & $3 / 8 / 17$ & $2 / 3 / 5$ & & $1 / 1 / 4$ & $\mathbf{2 9 / 4 0 / 6 5}$ \\
\hline $2 ; 04$ & $11 / 17 / 32$ & $1 / 1 / 1$ & $3 / 3 / 4$ & $2 / 2 / 8$ & $1 / 1 / 1$ & $2 / 2 / 4$ & $3 / 4 / 8$ & $2 / 3 / 9$ & $1 / 1 / 1$ & $4 / 4 / 14$ & $\mathbf{3 0 / 3 8 / 8 2}$ \\
\hline Total & $\mathbf{2 2 / 2 9 / 6 3}$ & $\mathbf{4 / 4 / 4}$ & $\mathbf{5 / 9 / 1 4}$ & $\mathbf{3 / 3 / 1 0}$ & $\mathbf{3 / 4 / 4}$ & $\mathbf{2 / 2 / 4}$ & $\mathbf{4 / 1 0 / 2 6}$ & $\mathbf{2 / 5 / 1 6}$ & $\mathbf{1 / 1 / 1}$ & $\mathbf{4 / 4 / 1 8}$ & $\mathbf{5 0 / 7 1 / 1 6 0}$ \\
\hline
\end{tabular}

Table 6: Distribution of verb lemmas / types / tokens with regard to inflectional classes

Until the end of the observed period, the child can be said to use verbs of inflectional classes $1-5$. But is there any evidence for the fact that the child really distinguishes these classes? A closer look at Katharina's data shows that her use of verb forms in the premorphological phase is reduced to verb forms which are the same for all five inflectional classes. Classdistinctive form use starts at $2 ; 3$, namely by the use of weak vs. strong past participles (e.g. class 1 umged(r)eht 'turned around' vs. class 3 umgefallen 'fallen over') and by the use of Umlaut in one incorrect stem form (class $3 *$ läf $(<--$ schläft) 'sleep'). The same holds true for age $2 ; 4$. Thus, Katharina seems to use a very simplified class system, corresponding to class differences between class 1 and class 3. Distinctive features of classes 2, 4 and 5 do not yet appear in her data.

\section{Emergence of mini-paradigms}

One important evidence for the beginning morphological productivity of a child is the emergence of morphological paradigms. Following Kilani-Schoch \& Dressler (2000), the development of verb paradigms can be seen as a gradual process involving different building steps: 


\section{1. "Pre-paradigm steps"}

Due to the low frequency of verb forms in the premorphological phase, first examples of preparadigm steps occur in the Katharina data only at 2;3. The following approximations of different verb forms of verb types have been found (step a, cf. Introduction to this volume):

(4) $2 ; 3$ schlafen 'to sleep': Inf. (sch)lafen - *3.Sg. Pres.Ind. *(sch)läf, *sch(l)af

$2 ; 3$ haben 'to have': 1.Sg. Pres.Ind. hab - *3.Sg. Pres.Ind. *ha

2;4 passen 'to fit': 3.Sg. Pres.Ind. passt - *3.Sg./PI. Pres.Ind. *pass, *pats, *passe, *patse

Simultaneously she also uses different verb forms of the same verb lemma, which are however either formulaic or context-bound (step b, cf. Introduction):

(5) 2;3 essen 'to eat': Inf. essen - 1.Sg. Pres.Ind. ich esse (no contrastive context to infinitive; both stand for Ich will essen 'I want to eat')

2;3 gehen 'to go': Inf. geh(e)n - 3.Sg. Pres.Ind. geht schon (formulaic: 'it's OK') 2.Sg. Imp. na geh! (formulaic: 'it's too bad')

2;4 machen 'to make': 3.Sg. Pres. Ind. macht nix (formulaic: 'no problem') 1.Sg. Pres.Ind. mach ich

2;4 gehen 'to go': Inf. geh(e)n - 3.Sg. Pres.Ind. geht net (formulaic: 'doesn't work')

It is intriguing that there is no time interval between first examples of pre-paradigm steps and the emergence of two-member mini-paradigms (see section 5.2.). Whereas clear examples of context-bound pre-paradigms are observed only at age $2 ; 3$, phonological approximations of different verb forms (mainly incorrect stem forms) can be found in the Katharina data until age $2 ; 9$.

\subsection{Two-member mini-paradigms}

First two-member mini-paradigms occur in Katharina's data at 2;3, i.e. at the onset of protomorphology.

The following table (tab. 7) lists all two-member mini-paradigms found in the observed period. ${ }^{17}$ As one can see, the first mini-paradigms consist of oppositions between Inf. and 1.Sg. Pres.Ind. or Inf and *PP (overgeneralized), followed by oppositions between Inf. and 3.Sg. Pres.Ind or 1. and 2. Sg. Pres.Ind. The first mini-paradigms belong to inflectional classes 1, 4 and to the group of suppletives, but no class-distinctive form use can be observed: all verb forms are morphotactically transparent.

\begin{tabular}{|c|c|c|c|c|c|}
\hline Age & lemma & infl. class & translation & form & category \\
\hline \multirow[t]{6}{*}{$2 ; 3$} & \multirow[t]{2}{*}{ holen } & \multirow[t]{2}{*}{ class 1} & \multirow[t]{2}{*}{ go for } & holen & Inf. \\
\hline & & & & hol ich & 1.Sg. Pres.Ind. \\
\hline & \multirow[t]{2}{*}{ reingeben } & \multirow[t]{2}{*}{ class 4} & \multirow[t]{2}{*}{ put into } & reingeben & Inf. \\
\hline & & & & $*_{\text {rein(ge)gebt }}$ & *PP \\
\hline & \multirow{2}{*}{ sitzen } & \multirow{2}{*}{ suppl } & \multirow{2}{*}{ sit } & sitzen & Int. \\
\hline & & & & ich silze & 1.Sg. Pres. Ind. \\
\hline \multirow[t]{4}{*}{$2 ; 4$} & \multirow[t]{2}{*}{ spielen } & \multirow[t]{2}{*}{ class 1} & \multirow[t]{2}{*}{ play } & (s)pielen & Int. \\
\hline & & & & (s)pielt & 3.Sg. Pres.Ind. \\
\hline & \multirow[t]{2}{*}{ haben } & \multirow[t]{2}{*}{ suppl:aux } & \multirow[t]{2}{*}{ have } & ich hab & 1.Sg. Pres.Ind. \\
\hline & & & & has(t) du & 2.Sg. Pres.Ind. \\
\hline
\end{tabular}

Table 7: Katharina's two-member mini-paradigms $(2 ; 0-2 ; 4)$

17 Out of the five criteria for the formation of mini-paradigms (cf. Introduction to this volume) all but recurrence hold for the paradigms presented here. 


\subsection{Three-member mini-paradigms}

In the period of Katharina's first 50 verb lemmas no example of a "true" - i.e. three-member mini-paradigm (cf. Introduction) has been found. The first three-member mini-paradigm appears only at the age of $2 ; 6$. It consists of verb forms of the class 1 verb machen 'to make':

(6) machen 'to make': Inf. machen - 1.Sg. Pres.Ind. mach ich - PP (g)emacht

It is interesting to note here that the lemma machen is used relatively often by Katharina's mother in child-directed speech. As can be seen in table 8, the lemma machen is ranked in the third position of the 10 most frequent verb lemmas in Katharina's input, corresponding to $4,4 \%(272 / 6178)$ of all verb tokens used. The most frequent lemma in the input is the lemma $\operatorname{sein}(19,4 \%)$, followed by the lemma schauen $(5,6 \%) .{ }^{18}$

\begin{tabular}{|c|c|c|c|c|c|}
\hline $\begin{array}{c}\text { frequency } \\
\text { ranking }\end{array}$ & lemma & infl. class & translation & tokens & $\begin{array}{c}\text { tokens / all } \\
\text { verb tokens }\end{array}$ \\
\hline 1. & sein & suppl:aux & be & 1198 & $19,4 \%$ \\
\hline 2. & schauen & class 1 & look & 348 & $5,6 \%$ \\
\hline 3. & machen & class 1 & make & 272 & $4,4 \%$ \\
\hline 4. & haben & aux & have & 245 & $4,0 \%$ \\
\hline 5. & müssen & mod & must & 210 & $3,4 \%$ \\
\hline 6. & haben & suppl:aux & have & 182 & $2,9 \%$ \\
\hline 7 & können & mod & can & 163 & $2,6 \%$ \\
\hline 8. & kommen & class 3' & come & 156 & $2,5 \%$ \\
\hline 9. & gehen & suppl & go & 142 & $2,3 \%$ \\
\hline 10. & sagen & class 1 & say & 129 & $2,1 \%$ \\
\hline
\end{tabular}

Table 8: 10 most frequent verb lemmas in Katharina's input

\subsection{Development of paradigm formation capacity}

The following table (tab. 9) gives an overview of the number of mini-paradigms observed in Katharina's data until age 2;6 (i.e. until the emergence of true mini-paradigms).

\begin{tabular}{|l|c|c|c|c|}
\hline Age & \multirow{2}{*}{$\begin{array}{c}\text { 2-member } \\
\text { mini- } \\
\text { paradigms }\end{array}$} & \multirow{2}{*}{$\begin{array}{c}\text { 3-member } \\
\text { mini- } \\
\text { paradigms }\end{array}$} & \multicolumn{2}{|c|}{ Paradigm values } \\
\cline { 4 - 5 } & & & $\mathbf{P}($ utt) & $\mathbf{P}($ lem) \\
\hline $2 ; 3$ & 3 & & $0,7 \%(3 / 461)$ & $10,3 \%(3 / 29)$ \\
\hline $2 ; 4$ & 2 & & $0,6 \%(2 / 335)$ & $6,7 \%(2 / 30)$ \\
\hline $2 ; 5$ & 5 & & $2,1 \%(5 / 241)$ & $12,2 \%(5 / 41)$ \\
\hline $2 ; 6$ & 7 & 2 & $2,5 \%(9 / 360)$ & $14,8 \%(9 / 61)$ \\
\hline
\end{tabular}

Table 9: Frequency of mini-paradigms $(2 ; 3-2 ; 6)$

Since the number of mini-paradigms attested in one corpus depends on sample size, we propose two sample-size-independent values for investigating the development of the paradigm formation capacity in a child. The first value ( $\mathrm{P}(\mathrm{utt}))$ is calculated by dividing the number of mini-paradigms by the number of analyzed utterances per month. The second value $(\mathrm{P}(\mathrm{lem}))$ sets the number of mini-paradigms into relation to the number of verb lemmas used in a given month of age. The paradigm values $\mathrm{P}(\mathrm{utt})$ and $\mathrm{P}(\mathrm{lem})$ are supposed to provide an objective base for the comparison of mini-paradigms across different corpora and languages (see also Aguirre and Katičić this volume). As can be seen in table 9, there is a remarkable spurt of $\mathrm{P}(\mathrm{utt})$ from $2 ; 4$ to $2 ; 5$. $\mathrm{P}(\mathrm{lem}$ ) shows a slight, continuous increase (with the exception of the value at $2 ; 4)$.

18 For input token frequency we have analyzed all child-directed utterances of Katharina's mother in the entire Katharina corpus $(1 ; 6-3 ; 0)$, yielding the total sum of 487 verb lemmas and 6178 verb tokens. 


\section{Morphological substitutions}

\subsection{Form errors}

The most frequent form errors in Katharina's data analyzed for this paper are incorrect stem forms. They are mainly used instead of 3.Sg. Pres.Ind. (e.g. 2;3 das läf $(<--$ schläft) 'this sleeps', Baby puck (<-- das Baby spuckt) 'the baby spits'). The fact that in other languages of our project true root forms do not occur in early acquisition phases, leads to comparative probabilistic evidence that these early stem forms are not true root forms (and thus morphologically conditioned), but might rather be phonologically conditioned. (Note that, until the age of $2 ; 3$, Katharina does not pronounce word-final consonant clusters such as $-k t$, $-s t$ or $-f t$ which are missing in the respective stem forms. At $2 ; 4$, she starts to vary between correct and incorrect pronounciation (e.g. pass / pats / passt'fit(s)')).

Other form errors in this phase are verb forms ending in shva - presumably approximations of infinitive forms - such as vorlese (<-- vorlesen) 'to read aloud' $(2 ; 3)$ and omissions of the prefix ge- in past participles, e.g. 2;3 runterfallen (<-- runtergefallen) 'fallen down'. Errors of this type are characteristic of German-speaking children (cf. also Elsen 1991; Behrens 1993; Bittner this volume).

\subsection{Class shifts}

Class shifts can be observed in past participles. The first class shift in PPs occurs at age 2;3, i.e. simultaneously with the emergence of two-member mini-paradigms. It's an overgeneralization of the class 4 verb reingehen towards class 1 : rein (ge)gebt (<-- reingegeben) 'put into'. Also later on, Katharina's overgeneralizations of PPs are mainly characterized by a class shift towards the only productive verb class 1 . Interestingly, overgeneralizations are observed only with those verb classes which do not take Ablaut in the PP', e.g. 2;4 weggeräumen (<-- weggeräumt, Inf. räumen) 'cleared away', 2;6 gefresst (<-- gefressen, Inf. fressen) 'eaten', 2;8 gehaltet ( <-- gehalten, Inf. halten) 'held', 3;0 gewascht ( <-- gewaschen, Inf. waschen) 'washed'. Thus, for Katharina, minimal morphotactic transparency (identity of the root) might be a condition for analogy. The same phenomenon has been observed by Lindner (1998: 171) for German children.

\subsection{Agreement errors}

The most frequent agreement errors ${ }^{20}$ observed in Katharina's data are root infinitives possibly resulting from omission of an auxiliary or modal verb, e.g. 2;3 Papi (sch)lafen (= Papi tut schlafen / Papi schläft) 'daddy is sleeping'. In languages such as German and French the homophony of infinitives with other verb forms (German: 1. and 3. Pl. Pres.Ind., French: PP (in verbs of the most frequent and productive 1. macroclass), 2.Pl. Pres.Ind.) might favour their early emergence (cf. Dressler, Bassano, Klampfer, Maillochon \& Sedlak 1999).

19) Similarly, PPs with Ablaut (i.e. from verb classes 2, 5 or respective suppletives) do not occur at all in the period of Katharina's first 50 verb lemmas (sec also section 4.5.).

20 Both grammatical and contextual agreement errors (i.e. agreement with and without overt subject) have been taken into consideration. 


\section{Conclusion}

In accordance with the definition of pre- and protomorphology (cf. Dressler \& Karpf 1995, Dressler 1997c, Introduction), Katharina's verb production in premorphology is limited to very few instances of rote-learned verb forms. In this phase, the child predominantly uses isolated verb particles (presumably due to their shortness (monosyllabic), prosodic saliency (always main stress) and morphological invariability) and iconic extragrammatic operations such as onomatopoetics in predicative function. Verb categories to emerge with Katharina in premorphology are the semantically unmarked 1 st and 3rd person present indicative and 2 nd person imperative.

The onset of protomorphology coincides with a clear verb spurt and with the occurrence of first two-member mini-paradigms. In the same month the first overgeneralization error is attested. Thus, for the child, a certain quantity of verb vocabulary seems to be a precondition for starting to create morphology. Similarly, a remarkable increase in the overall lexical diversity (measure D) is observed at the beginning of protomorphology. In this phase, infinitives and past participles appear, followed by first instances of 2nd person present indicative and compound past. No clear syntactic spurt can be attested at the onset of protomorphology. The fact that "true" (i.e. three-member) mini-paradigms start to emerge with Katharina clearly later than the first overgeneralization errors, raises the question whether evidence for the beginning morphological productivity of a child might be provided by the occurrence of several two-member mini-paradigms as well.

\section{References}

Allen, Shanley (1996): Assessing productivity in acquisition data from polysynthetic languages: an Inuktitut example. Paper presented at the 7th Int. Congress for the Study of Child Language, Istanbul, July 1996.

Anđel, Maja / Sabine Klampfer / Marianne Kilani-Schoch / Wolfgang U. Dressler / Melita Kovačević (in press): Acquisition of verbs in Croatian, French and Austrian German: an outline of a comparative analysis. Suvremena Lingvistika.

Bassano, Dominique, Isabelle Maillochon \& Elsa Eme (1998): Developmental changes and variability in the early lexicon: a study of French children's naturalistic productions. Journal of Child Language 25 ; 493-531.

Bates, Elizabeth / Philip S. Dale / Donna Thal (1995): Individual differences and their implications for theories of language development. In: P. Fletcher \& B. MacWhinney. eds. The handbook of child language. Oxford: Blackwell; 96-151.

Behrens, Heike (1993): Temporal reference in German child language: form and function of early verb use. $\mathrm{PhD}$ thesis. Universiteit van Amsterdam.

(1999): Was macht Verben zu einer besonderen Kategorie im Spracherwerb? In: J. Meibauer \& M. Rothweiler. eds. Das Lexikon im Spracherwerb. Tübingen: Francke; 32-50.

Bittner, Andreas (1996): Starke "schwache" und schwache "starke" Verben. Tübingen: Narr.

Dressler, Wolfgang U. (1997a): Universals, typology, and modularity in Natural Morphology. In: R. Hickey \& S. Puppel. eds. Language history and language modelling. Fs. J. Fisiak. Berlin: de Gruyter; 1399-1421.

- (1997b): On productivity and potentiality in inflectional morphology. CLASNET Working Papers (Montréal) 7; 3-22.

(1997c): Introduction. Papers and Studies in Contrastive Linguistics 33; 9-14.

- (1997): ed. Studies in Pre- and Protomorphology. Wien: Verlag der Österreich. Akademie der Wissenschaften.

- (in prep.): German verb inflection. ms. 
- / Dominique Bassano / Sabine Klampfer / Isabelle Maillochon / Maria Sedlak (1999): Vergleich des Erstspracherwerbs des französischen und österreichisch-deutschen Verbalsystems. Anzeiger der phil.-histor. Klasse der Österr. Akademie der Wissenschaften, 134. Jahrgang; 109 112.

- / Annemarie Karpf (1995): The theoretical relevance of pre- and protomorphology in language acquisition. Yearbook of Morphology 1994; 99-122.

- / Sabine Klampfer (2000): On the emergence of inflectional classes - the case of Austrian German (with a typological perspective). Paper presented at the Max-Planck-Institute for Evolutionary Anthropology, Leipzig, February 2000.

Elsen, Hilke (1991): Erstspracherwerb: der Erwerb des deutschen Lautsystems. Wiesbaden: DUV.

- (1998): The acquisition of past participles: one or two mechanisms? In: R. Fabri, A. Ortmann \& T. Parodi. eds.; 134-149.

Fabri, Ray / Albert Ortmann / Teresa Parodi (eds) (1998): Models of inflection. Tübingen: Niemeyer.

Kilani-Schoch, Marianne / Wolfgang U. Dressler (2000): The emergence of verb paradigms in two French corpora as an illustration of general problems of pre- and protomorphology. Poster presented at the $9^{\text {th }}$ Int. Morphology Meeting, February 2000.

Klampfer, Sabine / Isabelle Maillochon / Dominique Bassano / Wolfgang U. Dressler (1999): On early acquisition of verb inflection in Austrian German and French: the case of person and number marking. Wiener Linguistische Gazette 64-65; 1-29.

Klampfer, Sabine / Ralf Vollmann / Wolfgang U. Dressler (1999): The emergence of verb morphology in Austrian German. Paper presented at the 8th Int. Congress for the Study of Child Language, San Sebastian, July 1999.

Lindner, Katrin (1998): Overgeneralization revisited: the case of German past participles. In: R. Fabri, A. Ortmann \& T. Parodi. eds.; $152-174$.

MacWhinney, Brian (2000): The CHILDES project: tools for analyzing talk. Vol. I: Transcription, format and programs. Mahwah, NJ: Lawrence Erlbaum Associates.

Marchman, Virginia A. / Elizabeth Bates (1994): Continuity in lexical and morphological development: a test of the critical mass hypothesis. Journal of Child Language 21; 339-366.

Müller, Brigitta (1997): The acquisition of early morphology: a case study. In: W. U. Dressler ed.; 6171.

Peters, Ann M. / Lise Menn (1993): False starts and filler syllables: ways to learn grammatical morphemes. Language 69/4; 742-777.

Richards, Brian / David Malvern. (1999): The application of a new measure of lexical diversity to preschool children. Paper presented at the 8th Int. Congress for the Study of Child Language, San Sebastian, July, 1999.

Sedlak, Maria / Sabine Klampfer / Brigitta Müller / Wolfgang U. Dressler (1998): The acquisition of number in Austrian German: a case study on the early stages. Antwerp Papers in Linguistics; 51-76.

Vollmann, Ralf / Maria Sedlak / Brigitta Müller / Maria Vassilakou (1997): Early verb inflection and noun plural formation in four Austrian children. Papers and Studies in Contrastive Linguistics $33 ; 59-78$. 